\title{
Knockdown of GluA2 induces apoptosis in non-small-cell lung cancer A549 cells through the p53 signaling pathway
}

\author{
HONG-YAN ZHANG, WEI YANG and JI-BIN LU
}

Department of Thoracic Surgery, Shengjing Hospital of China Medical University, Shenyang, Liaoning 150000, P.R. China

Received February 8, 2016; Accepted March 9, 2017

DOI: $10.3892 / 01.2017 .6234$

\begin{abstract}
. $\alpha$-amino-3-hydroxy-5-methyl-4-isoxazolepropionic acid (AMPA) receptors are important glutamatergic receptors that mediate fast excitatory synaptic transmission in the brain. Previous studies have demonstrated that glutamate ionotropic receptor AMPA type subunit 2 (GluA2), one of the four subunits that comprise AMPA receptors, is a potential novel marker for poor prognosis in patients with human lung cancer. However, the mechanisms of GluA2-induced apoptosis, proliferation and migration in lung cancer remain unknown. The present study aimed to explore the mechanisms underlying these effects of GluA2 in human lung cancer by silencing GluA2 in A549 cells. Using the Cell Counting Kit-8 assay, western blot analysis and acridine orange/ethidium bromide staining, downregulation of GluA2 was revealed to significantly inhibit the proliferation and significantly promote the apoptosis of A549 cells. Knockdown of GluA2 was also revealed to be associated with increased caspase-3 activity, increased Bcl-2-associated $\mathrm{X}$ protein and Bcl-2-associated death promoter (Bad) expression, and decreased expression of B-cell lymphoma-2, p-Bad and $\mathrm{X}$-linked inhibitor of apoptosis protein. In addition, GluA2 silencing upregulated cellular tumor antigen p53

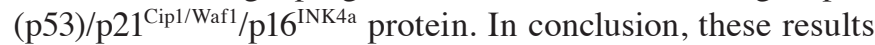
indicate that the effects of GluA2 in lung cancer are mediated

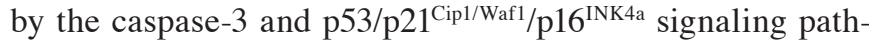
ways. Therefore, GluA2 may be a potential novel therapeutic target for the treatment of lung cancer.
\end{abstract}

\section{Introduction}

Lung cancer is the primary cause of cancer-associated mortality in males and females worldwide (1). Lung cancer was estimated

Correspondence to: Dr Ji-Bin Lu, Department of Thoracic Surgery, Shengjing Hospital of China Medical University, 36 Sanhao Street, Shenyang, Liaoning 150000, P.R. China

E-mail: lujb@sj-hospital.org

Key words: $\alpha$-amino-3-hydroxy-5-methyl-4-isoxazolepropionic acid receptor, glutamate ionotropic receptor $\alpha$-amino-3-hydroxy- 5 -methyl-4-isoxazolepropionic acid type subunit 2, apoptosis, A549 cells, lung cancer to be responsible for $\sim 1.6$ million mortalities worldwide in 2012 and $\sim 20 \%$ of cancer-associated mortality $(1,2)$. The majority of lung cancer cases ( 90\%) are non-small cell lung cancer (NSCLC), which comprises a number of subtypes driven by the activation of various oncogenes $(3,4)$. Typically, $50 \%$ of NSCLC cases are diagnosed at an advanced stage $(5,6)$. For the majority of patients with NSCLC, chemotherapy represents the mainstay of treatment and prognosis remains poor (5-7). Therefore, improved understanding of the molecular pathogenesis of NSCLC and the identification of novel therapeutic targets for NSCLC may facilitate the early detection and improved survival, respectively, of patients with NSCLC.

Glutamate ionotropic receptor AMPA type subunit 2 (GluA2) encodes an $\alpha$-amino-3-hydroxy-5-methyl-4-isoxazolepropionic acid (AMPA) glutamate receptor, which acts as an excitatory neurotransmitter at numerous synapses in the central nervous system $(8,9)$. AMPA type subunit 2 (GluA2), one of the four subunits of AMPA receptors, is a potential novel marker for poor prognosis in patients with human lung cancer, in which it is typically deregulated (10). However, glutamate signaling pathways have also been identified in various non-excitable tissues, in addition to being implicated in several diseases, including cancer $(11,12)$. Binding of glutamate to its receptors activates Src family kinases and downstream signaling pathways, which stimulates proliferation, apoptosis resistance, migration and invasion in different cancer cell lines, including hepatocellular carcinoma, clear cell renal carcinoma and glioma cells (11-13). Choi et al (14) demonstrated that the expression of GluA2 is associated with an improved prognosis of patients with advanced serous papillary ovarian adenocarcinoma. Herner et al (15) revealed that glutamate-mediated GluA2 activation increased the invasion and migration of pancreatic cancer cells via activation of the classical mitogen-activated protein kinase signaling pathway. Although GluA2 serves an important role in the development and progression of various types of cancer, limited research is available regarding its effect on the proliferation of NSCLC cells. Therefore, the effects of GluA2 in lung cancer cells, in addition to the molecular mechanisms underlying these effects, requires additional study.

The present study aimed to explore the mechanism underlying GluA2 deregulation in NSCLC. The effects of GluA2-knockdown were investigated in in vitro experiments, including an apoptosis assay. GluA2 was revealed to induce apoptosis via caspase-dependent and cellular tumor antigen 
p53 (p53) signaling pathways in human A549 NSCLC cells. The results of the current study may aid in the development of novel treatments for NSCLC.

\section{Materials and methods}

Reagents. Antibodies directed against B-cell lymphoma-2 (Bcl-2; cat. no., D198628) and Bcl-2-associated X protein (Bax; cat. no., D120073) were purchased from Sangong Biotech Co., Ltd. (Shanghai, China). Antibodies directed against GluA2 (cat. no., 13607), Blc-2-associated death promoter (Bad; cat. no., 9292), phosphorylated (p)-Bad (cat. no., 9291) and p53 (cat. no., 9282), and $\beta$-actin (cat. no., 3700) were obtained from Cell Signaling Technology, Inc. (Danvers, MA, USA). The anti-X-linked inhibitor of apoptosis protein (XIAP; cat. no., 2042) antibody was obtained from Cell Signaling Technology, Inc., the anti-p21 Cip1/Waf1 antibody (cat. no., 621134) was purchased from BD Pharmingen (San Diego, CA, USA) and the anti-p16 $6^{\mathrm{INK} 4 \mathrm{a}}$ antibody (cat. no., sc-73434) was obtained from Santa Cruz Biotechnology, Inc. (Dallas, TX, USA). Other chemicals were purchased from Sigma-Aldrich (Merck KGaA, Darmstadt, Germany). The GluA2-shRNA plasmid kit (cat. no., C01001) was purchased from GeneChem Co., Ltd. (Shanghai, China).

RNA interference. Cells were transfected using Lipofectamine ${ }^{\circledR}$ 2000 reagent (Thermo Fisher Scientific, Inc., Waltham, MA, USA), according to the manufacturer's protocol. Two sequence-validated and knockdown-warranted GluA2-siRNA were used together to improve the efficacy of knockdown (siRNA 1, ATATTGGAGTGAAGTGGACAA and siRNA 2, GGAGCTCTCCTTAGCTTGATT; Shanghai GenePharma Co., Ltd., Shanghai, China). Commercial 6-carboxyfluorescein-tagged, negative control (NC) scrambled siRNAs (5'-UCCUCCGAACGUGUCACGUTT-3' and 5'-ACGUGA CACGUUCGGAGAATT-3'; Shanghai GenePharma Co., Ltd.) were used together as a control for efficiency and non-specific side effects.

A549 cell culture. The lung cancer A549 cell line was provided by the Department of Thoracic Surgery of the Second Affiliated Hospital of China Medical University (Shenyang, China) and cultured in RPMI-1640 medium containing $10 \%(\mathrm{v} / \mathrm{v})$ heat-inactivated fetal bovine serum (Gibco; Thermo Fisher Scientific, Inc.), $50 \mathrm{U} / \mathrm{ml}$ penicillin and $100 \mu \mathrm{g} / \mathrm{ml}$ streptomycin (Invitrogen; Thermo Fisher Scientific, Inc.) at $37^{\circ} \mathrm{C}$ in an incubator containing humidified air with $5 \%(\mathrm{v} / \mathrm{v}) \mathrm{CO}_{2}$.

Cell Counting Kit-8 (CCK-8) cell proliferation assay. A549 cells were transfected with the GluA2-siRNAs or scrambled siRNAs. A total of $24 \mathrm{~h}$ after transfection, cells were transferred into 96 -well plates at a density of $2 \times 10^{3}$ cells/well. Cell viability was assessed using a CCK-8 (Dojindo Molecular Technologies, Inc., Kumamoto, Japan) assay at days 1, 2 and 4 after transfection.

Acridine orangelethidium bromide (AO/EB) fluorescence staining. A549 cells were transfected with the GluA2-siRNAs or scrambled siRNA. The cells were incubated with
AO/EB solution (cat. no., CA1140; Beijing Solarbio Science \& Technology Co., Ltd., Beijing, China) for $5 \mathrm{~min}$ at room temperature, according to a previously described method (16). Cellular morphological changes were subsequently examined using fluorescence microscopy; live cells were stained green, apoptotic cells, yellow and necrotic cells, red. The percentage of apoptotic cells was calculated using the following formula: Apoptotic rate $(\%)=($ number of apoptotic cells/total number of cells)x 100 , as previously described $(17,18)$.

Western blot analysis. A549 cells were transfected with the chosen GluA2-siRNA or scrambled siRNA. Cell lysates were prepared for western blotting $48 \mathrm{~h}$ after transfection, in order to determine the efficiency of gene expression ablation. The amount of protein obtained was quantified using a bicinchoninic acid protein assay kit (Beyotime Institute of Biotechnology, Shanghai, China). Protein samples ( $60 \mu \mathrm{g} / \mathrm{lane})$ were separated on a $10 \%$ gel via SDS-PAGE and blotted onto nitrocellulose membranes. The blots were incubated with the previously described antibodies specific for Bcl-2 (dilution, 1:1,000), Bax (dilution, 1:1,000), Bad (dilution, 1:500), p-Bad (dilution, 1:500), GluA2 (dilution, 1:1,000), XIAP (dilution, 1:500), p53 (dilution, 1:500), p21 $1^{\mathrm{Cip} / \text { Wafl }}$ (dilution, 1:500), p16 $6^{\mathrm{INK} 4 \mathrm{a}}$ (dilution, $1: 500$ ) and $\beta$-actin (dilution, $1: 1,000$ ) overnight at $4^{\circ} \mathrm{C}$, then at $37^{\circ} \mathrm{C}$ for $2 \mathrm{~h}$. Subsequent to washing in PBS and incubating with secondary antibodies (cat. no., v926-32211 for rabbit and v926-32210 for mouse; dilution, 1:10,000; LI-COR Biosciences, Lincoln, NE, USA) at room temperature for $1 \mathrm{~h}$, the blots were visualized using an enhanced chemiluminescence reagent (GE Healthcare Life Sciences, Shanghai, China) and normalized to $\beta$-actin using the software from an Odyssey imaging system (version 3.0; LI-COR Biosciences).

Caspase-3 activity assay. A total of $5 \times 10^{3}$ cells were seeded into 96-well cell culture plates. Following transfection with GluA2-siRNA or scrambled siRNA for $48 \mathrm{~h}$, apoptotic rates were measured based on the activation of caspase- 3 using a Caspase-3 Activity Assay kit (Beyotime Institute of Biotechnology), according to the manufacturer's protocol.

Statistical analysis. Data were obtained from $\geq 3$ independent experiments. All statistical analysis was performed in SPSS 19.0 (IBM SPSS, Armonk, NY, USA) and results were illustrated using GraphPad Prism 5.0 (GraphPad Software, Inc., La Jolla, CA, USA). Results are presented as the mean \pm standard deviation. Differences between two groups were evaluated using an unpaired Student's t-test; differences between multiple groups were evaluated with an ANOVA followed by Tukey's multiple comparison test. $\mathrm{P}<0.05$ was considered to indicate a statistically significant difference.

\section{Results}

GluA2 knockdown suppresses the proliferation of A549 cells. Two GluA2 shRNAs were designed and tested. The first shRNA did not produce efficient depletion of GluA2 (data not shown). However, successful suppression of GluA2 using the second shRNA was verified using western blotting (Fig. 1A). The second shRNA was thus used for the following experiments. It was identified that GluA2 depletion markedly 
A
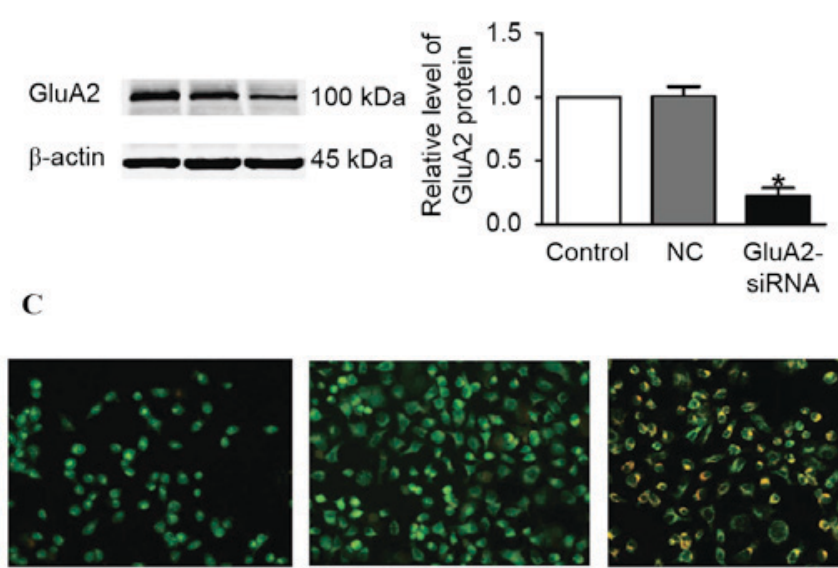

Control

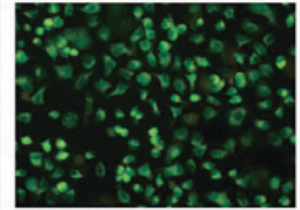

NC

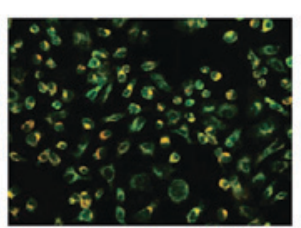

GluA2-siRNA
B

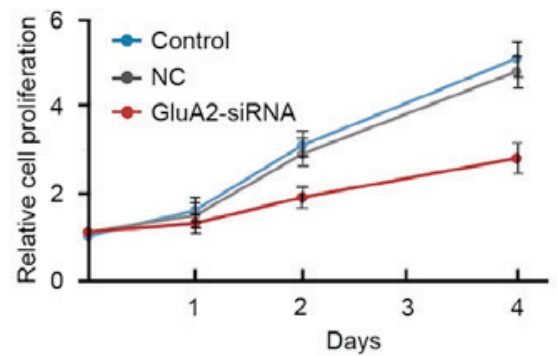

D

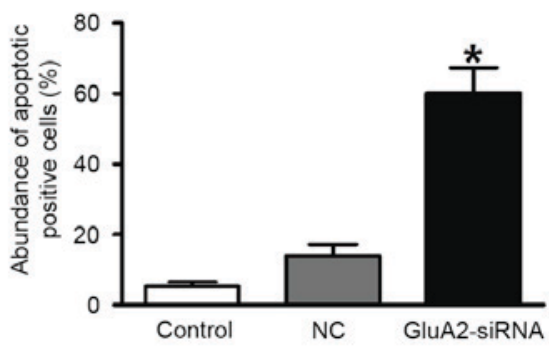

Figure 1. Silencing GluA2 expression inhibits the proliferation of A549 cells. (A) GluA2 expression determined by western blot analysis following siRNA transfection. (B) Cell proliferation determined by Cell Counting Kit-8 assay. (C) AO/EB staining was performed to apoptosis, where yellow staining indicates apoptotic cells. Magnification, x200. (D) Quantification of the amount of apoptotic cells from AO/EB staining. "P<0.05 vs. the control group. AO/EB, acridine orange/ethidium bromide; NC, negative control; siRNA, small interfering RNA; GluA2, glutamate ionotropic receptor AMPA type subunit 2.

inhibited A549 cell proliferation compared to an untransfected control (Fig. 1B).

Silencing GluA2 expression induces the apoptosis of A549 cells. To assess whether increased apoptosis was associated with the decrease in cell proliferation observed following GluA2 knockdown, AO/EB staining was used to detect apoptotic cells. The results from fluorescence microscopy analysis are illustrated in Fig. 1C and D. A total of three cell stages were recognized as follows: Live cells (control cells), apoptotic cells (NC cells) and necrotic cells (GluA2-shRNA-transfected cells). GluA2 knockdown significantly increased the amount of apoptotic cells compared with the control group $(\mathrm{P}<0.05$; Fig. 1D).

Silencing GluA2 expression activates caspase-dependent proapoptotic signaling pathways in A549 cells. To explore the mechanisms by which GluA2 knockdown induces apoptosis in A549 cells, the levels of downstream proteins of the GluA2 apoptotic pathway were measured by western blotting, including Bax, Bcl-2, Bad, p-Bad and XIAP. Fig. 2 demonstrates that silencing of GluA2 significantly upregulated Bad and Bax expression, and significantly downregulated p-Bad and $\mathrm{Bcl}-2$ expression (all $\mathrm{P}<0.05$ vs. the control group; Fig. $2 \mathrm{~A}$ and B). Knockdown of GluA2 significantly decreased expression of XIAP protein ( $\mathrm{P}<0.05$ vs. the control group; Fig. $2 \mathrm{C}$ ), which is an essential antiapoptotic protein. In addition, relative caspase- 3 activity was significantly increased by 2.2-fold following to GluA2-shRNA transfection $(\mathrm{P}<0.05$ vs. the control group; Fig. 2D).

Silencing GluA2 expression decreases the expression of p53, p21 Cipl/Wafl and p16 ${ }^{\text {INK4a }}$ in A549 cells. The expression of $\mathrm{p} 53$ (Fig. 3A), p21 ${ }^{\text {Cipl/Waf1 (Fig. 3B) and p16 }}{ }^{\mathrm{INK} 4 \mathrm{a}}$ (Fig. 3C) proteins was revealed to be significantly upregulated in A549 cells following GluA2-shRNA transfection (all $\mathrm{P}<0.05$ ). These observations indicate that the p53 signaling pathway serves an important role in the GluA2-induced apoptosis of A549 cells.

\section{Discussion}

In the present study, knockdown of GluA2 was revealed to have a potent antiproliferative effect on A549 cells by inducing apoptosis and reducing proliferation in vitro. The results of the present study also identified that activation of caspase-3-dependent and p53-dependent signaling pathways are important mechanisms for these effects of GluA2. Therefore, the present study has elucidated the signaling pathway by which GluA2 affects lung cancer.

AMPA receptors are a major class of glutamatergic receptors, which serve essential roles in normal neuronal activity, including synaptic plasticity, synaptic scaling, learning and memory, in addition to synaptogenesis and the formation of neuronal circuitry $(19,20)$. AMPA receptors are heterotetrameric proteins composed of GluA1-4 subunits $(21,22)$. The predominant AMPA receptor in the adult cerebral neocortex and hippocampus is GluA2 $(23,24)$. GluA2 is also unique, as its inclusion into the heterotetramer renders AMPA receptors significantly less permeable to $\mathrm{Ca}^{2+}(25)$. AMPA receptor-mediated signals may be associated with carcinogenesis due to their regulation of the differentiation, proliferation and migration of embryonic stem cells $(26,27)$. This hypothesis was confirmed in a number tumor types, including astrocytoma, glioblastoma, breast carcinoma, lung carcinoma, colon adenocarcinoma and prostate carcinoma (28-31). However, the mechanism by which GluA2 contributes to human lung carcinogenesis remains poorly understood. In the present study, the ratio of $\mathrm{Bcl}-2 / \mathrm{Bax}$ significantly increased in the GluA2-siRNA-transfected group compared with the control group, suggesting that the 
A
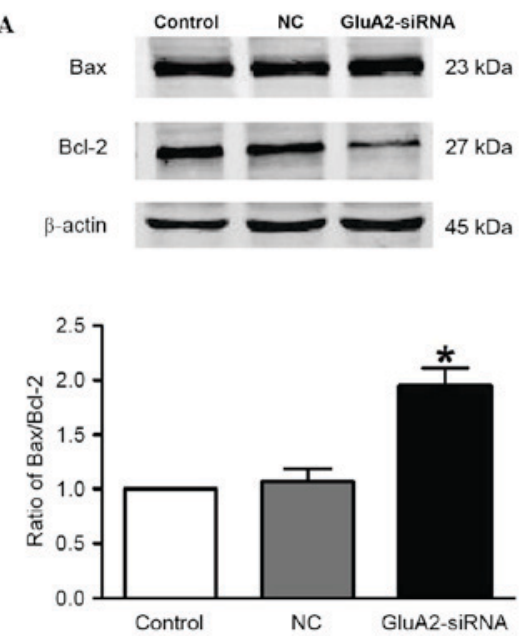

C
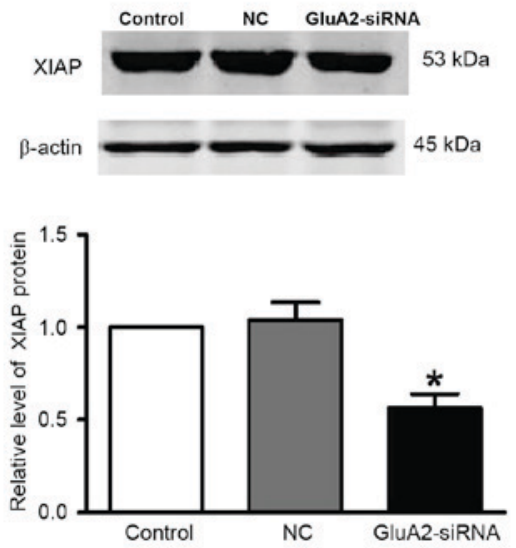

B
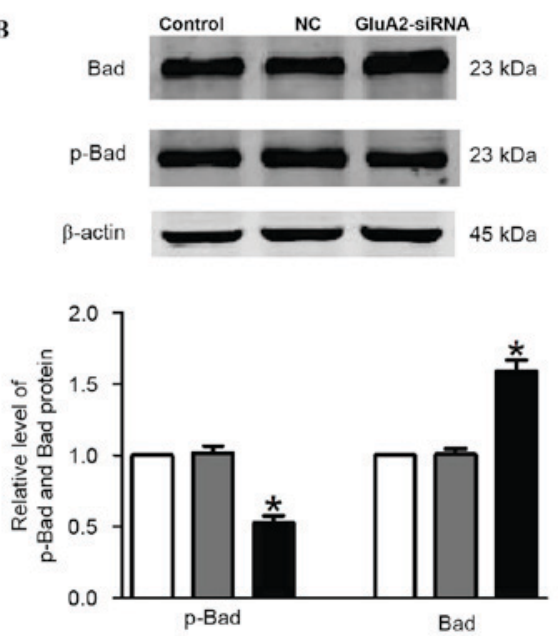

D

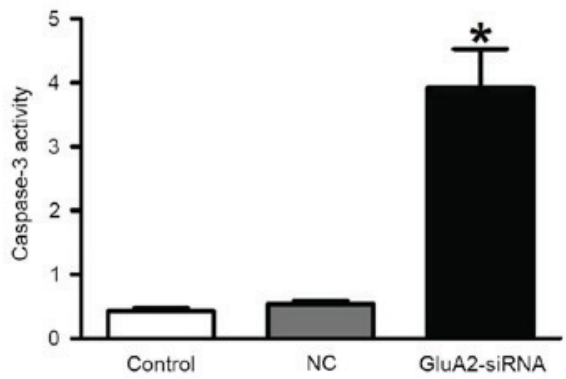

Figure 2. Silencing GluA2 expression alters p-Bad, Bad, Bax, Bcl-2 and XIAP expression, and increases caspase-3 activity. Western blotting was used to detect (A) Bax and Bcl-2 (increased and decreased, respectively), (B) p-Bad and Bad (decreased and increased, respectively), and (C) XIAP (decreased) expression in A549 cells transfected with GluA2-siRNA. (D) Caspase-3 activity was increased by GluA2-siRNA treatment. "P<0.05 vs. the control group. GluA2, glutamate ionotropic receptor AMPA type subunit 2; Bcl-2, B-cell lymphoma-2; Bax, Bcl-2-associated X protein; Bad, Bcl-2-associated death promoter; p-, phosphorylated; XIAP, X-linked inhibitor of apoptosis protein; siRNA, small interfering RNA; NC, negative control.
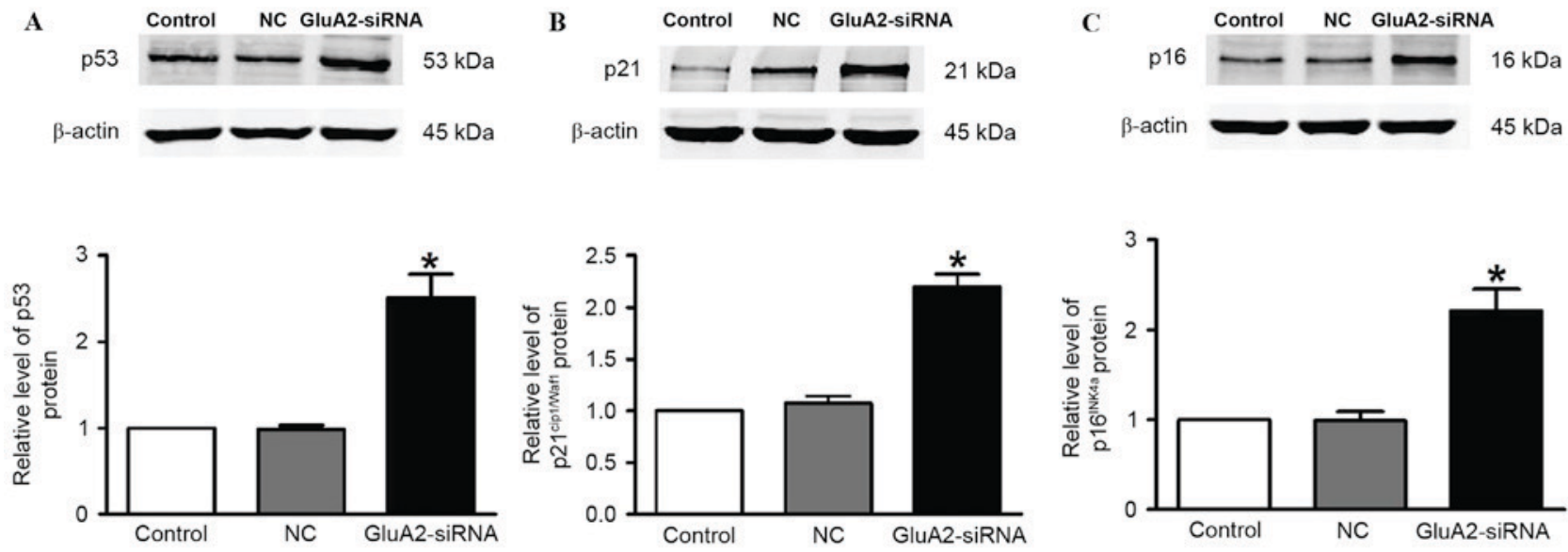

Figure 3. Silencing GluA2 expression increases the expression of p53, p21 $1^{\text {Cipl/Waf1 }}$ and $\mathrm{p} 16^{\text {INK4a }}$ in A549 cells. Western blotting was used to detect (A) p53, (B) $\mathrm{p}^{\text {Cipl/Wafl }}$ and (C) $\mathrm{p}^{\mathrm{INK4a}}$ protein levels. ${ }^{\text {P }}<0.05$ vs. the control group. GluA2, glutamate ionotropic receptor AMPA type subunit 2; NC, negative control; siRNA, small interfering RNA; p53, cellular tumor antigen p53.

knockdown of GluA2 induced apoptosis in the A549 cells. In addition, Bad, a member of the Bcl-2 family that normally binds to the Bcl-2/Bcl-extra larger (Bcl-xL) complex and triggers apoptosis, was significantly increased in this group.
p-Bad dissociates from the Bcl-2/Bcl-xL complex, resulting in the suppression of apoptosis (32). However, p-Bad was significantly decreased in the GluA2-siRNA-transfected group compared with the control group in the present study. 
Levels of XIAP were also significantly decreased following knockdown of GluA2. XIAP interacts with caspase-3 to inhibit its activation, which normally leads to cell death (33). Caspase-3 activity was significantly decreased in the GluA2-siRNA-transfected group in the current study. These results indicate that the caspase-3 signaling pathway serves an important role in the GluA2-induced apoptosis of lung cancer A549 cells.

The p53 signaling pathway serves an important role in apoptosis in lung cancer $(34,35)$. Mutations to p53 protein are common in lung carcinoma (36); p53 has a antitumorigenic effect in NSCLC (37). The present study demonstrated that caspase-3 activity in lung cancer cells significantly increased following silencing of GluA2. It was identified that GluA2 silencing was able to induce apoptosis in A549 cells, and this effect appeared to be conferred by the significant increase in $\mathrm{p} 53$, p $21^{\text {Cip1/Waf1 }}$ and $\mathrm{p} 16^{\mathrm{INK} 4 \mathrm{a}}$ expression observed following GluA2-knockdown. This indicates that the $\mathrm{p} 53 / \mathrm{p} 21^{\text {Cip1/Waf1 }} / \mathrm{p} 16^{\text {INK4a }}$ signaling pathway is associated with the GluA2-induced apoptosis of lung cancer A549 cells.

The present results demonstrated that the silencing of GluA2 expression may inhibit the proliferation, and promote the apoptosis of lung cancer A549 cells. Therefore, administration of an AMPA receptor antagonist may inhibit tumor growth. The AMPA receptor antagonist talampanel has been demonstrated to be well tolerated, but exerted no antitumorigenic activity as a single agent, in a phase II clinical trial of patients with recurrent glioma (38). Additional studies are required to evaluate the potential benefit of AMPA inhibitors in the treatment of lung cancer, particularly the types that do not respond well to current chemotherapy regimens.

In conclusion, the results of the present study indicate that the silencing of GluA2 may inhibit the proliferation, and promote the apoptosis of lung cancer A549 cells. These effects were determined to be associated with the caspase-3

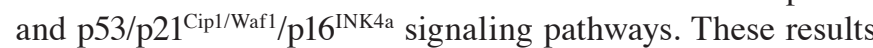
suggest that GluA2 may be a potential novel therapeutic target for the treatment of lung cancer.

\section{References}

1. Ferlay J, Soerjomataram I, Dikshit R, Eser S, Mathers C, Rebelo M, Parkin DM, Forman D and Bray F: Cancer incidence and mortality worldwide: Sources, methods and major patterns in GLOBOCAN 2012. Int J Cancer 136: E359-E386, 2015.

2. Sullivan I and Planchard D: ALK inhibitors in non-small cell lung cancer: The latest evidence and developments. Ther Adv Med Oncol 8: 32-47, 2016.

3. Ettinger DS, Akerley W, Bepler G, Blum MG, Chang A, Cheney RT, Chirieac LR, D'Amico TA, Demmy TL, Ganti AK, et al: Non-small cell lung cancer. J Natl Compr Canc Netw 8: 740-801, 2010.

4. Larsen JE, Cascone T, Gerber DE, Heymach JV and Minna JD: Targeted therapies for lung cancer: Clinical experience and novel agents. Cancer J 17: 512-527, 2011.

5. Reck M, Popat S, Reinmuth N, De Ruysscher D, Kerr KM and Peters S; ESMO Guidelines Working Group: Metastatic non-small-cell lung cancer (NSCLC): ESMO clinical practice guidelines for diagnosis, treatment and follow-up. Ann Oncol 25 (Suppl 3): iii27-iii39, 2014.

6. Bordi P, Del Re M, Danesi R and Tiseo M: Circulating DNA in diagnosis and monitoring EGFR gene mutations in advanced non-small cell lung cancer. Transl Lung Cancer Res 4: 584-597, 2015.

7. Hall RD, Le TM, Haggstrom DE and Gentzler RD: Angiogenesis inhibition as a therapeutic strategy in non-small cell lung cancer (NSCLC). Transl Lung Cancer Res 4: 515-523, 2015.
8. Priya A, Johar K, Nair B and Wong-Riley MT: Nuclear respiratory factor 2 regulates the transcription of AMPA receptor subunit GluA2 (Gria2). Biochim Biophys Acta 1843: 3018-3028, 2014.

9. Isaac JT, Ashby MC and McBain CJ: The role of the GluR2 subunit in AMPA receptor function and synaptic plasticity. Neuron 54: 859-871, 2007.

10. Stepulak A, Luksch H, Gebhardt C, Uckermann O, Marzahn J, Sifringer M, Rzeski W, Staufner C, Brocke KS, Turski L and Ikonomidou C: Expression of glutamate receptor subunits in human cancers. Histochem Cell Biol 132: 435-445, 2009.

11. Nedergaard M, Takano T and Hansen AJ: Beyond the role of glutamate as a neurotransmitter. Nat Rev Neurosci 3: 748-755, 2002.

12. Hu H, Takano N, Xiang L, Gilkes DM, Luo W and Semenza GL: Hypoxia-inducible factors enhance glutamate signaling in cancer cells. Oncotarget 5: 8853-8868, 2014.

13. de Groot JF, Piao Y, Lu L, Fuller GN and Yung WK: Knockdown of GluR1 expression by RNA interference inhibits glioma proliferation. J Neurooncol 88: 121-133, 2008.

14. Choi CH, Choi JJ, Park YA, Lee YY, Song SY, Sung CO, Song T, Kim MK, Kim TJ, Lee JW, et al: Identification of differentially expressed genes according to chemosensitivity in advanced ovarian serous adenocarcinomas: Expression of GRIA2 predicts better survival. Br J Cancer 107: 91-99, 2012.

15. Herner A, Sauliunaite D, Michalski CW, Erkan M, De Oliveira T, Abiatari I, Kong B, Esposito I, Friess H and Kleeff J: Glutamate increases pancreatic cancer cell invasion and migration via AMPA receptor activation and Kras-MAPK signaling. Int J Cancer 129: 2349-2359, 2011

16. Mcgahon AJ, Martin SJ, Bissonnette RP, Mahboubi A, Shi Y, Mogil RJ, Nishioka WK and Green DR: The end of the (Cell) line: Methods for the study of apoptosis in vitro. Method Cell Biol 46: 153-185, 1995.

17. Ni B, Bai FF, Wei Y, Liu MJ, Feng ZX, Xiong QY, Hua LZ and Shao GQ: Apoptosis induced by lipid-associated membrane proteins from Mycoplasma hyopneumoniae in a porcine lung epithelial cell line with the involvement of caspase 3 and the MAPK pathway. Genet Mol Res 14: 11429-11443, 2015.

18. He Y, Chen W, Hu Y, Luo B, Wu L, Qiao Y, Mo Q, Xu R, Zhou Y, Ren Z, et al: E. adenophorum induces cell cycle and apoptosis of renal cells through mitochondrial pathway and caspase activation in Saanen Goat. PLoS One 10: e0138504, 2015.

19. Borges K and Dingledine R: AMPA receptors: Molecular and functional diversity. Prog Brain Res 116: 153-170, 1998.

20. Henley JM and Wilkinson KA: AMPA receptor trafficking and the mechanisms underlying synaptic plasticity and cognitive aging. Dialogues Clin Neurosci 15: 11-27, 2013.

21. Serulle Y, Arancio O and Ziff EB: A role for cGMP-dependent protein kinase II in AMPA receptor trafficking and synaptic plasticity. Channels 2: 230-232, 2008.

22. Priya A, Johar K, Nair B and Wong-Riley MT: Specificity protein 4 (Sp4) regulates the transcription of AMPA receptor subunit GluA2 (Gria2). Biochim Biophys Acta 1843: 1196-1206, 2014.

23. Craig AM, Blackstone CD, Huganir RL and Banker G: The distribution of glutamate receptors in cultured rat hippocampal neurons: Postsynaptic clustering of AMPA-selective subunits. Neuron 10: 1055-1068, 1993.

24. Wenthold RJ, Petralia RS, Blahos J II and Niedzielski AS: Evidence for multiple AMPA receptor complexes in hippocampal CA1/CA2 neurons. J Neurosci 16: 1982-1989, 1996.

25. Sommer B, Köhler M, Sprengel R and Seeburg PH: RNA editing in brain controls a determinant of ion flow in glutamate-gated channels. Cell 67: 11-19, 1991.

26. Ikonomidou C, Bosch F, Miksa M, Bittigau P, Vöckler J, Dikranian K, Tenkova TI, Stefovska V, Turski L and Olney JW: Blockade of NMDA receptors and apoptotic neurodegeneration in the developing brain. Science 283: 70-74, 1999.

27. Joo JY, Kim BW, Lee JS, Park JY, Kim S, Yun YJ, Lee SH, Lee $\mathrm{SH}$, Rhim $\mathrm{H}$ and Son $\mathrm{H}$ : Activation of NMDA receptors increases proliferation and differentiation of hippocampal neural progenitor cells. J Cell Sci 120: 1358-1370, 2007.

28. Yoshioka A, Ikegaki N, Williams M and Pleasure D: Expression of N-methyl-D-aspartate (NMDA) and non-NMDA glutamate receptor genes in neuroblastoma, medulloblastoma and other cells lines. J Neurosci Res 46: 164-178, 1996.

29. Takeda M, Haga M, Yamada H, Kinoshita M, Otsuka M, Tsuboi S and Moriyama Y: Ionotropic glutamate receptors expressed in human retinoblastoma Y79 cells. Neurosci Lett 294: 97-100, 2000.

30. Rzeski W, Ikonomidou C and Turski L: Glutamate antagonists limit tumor growth. Biochem Pharmacol 64: 1195-1200, 2002. 
31. Ishiuchi S, Yoshida Y, Sugawara K, Aihara M, Ohtani T, Watanabe T, Saito N, Tsuzuki K, Okado H, Miwa A, et al: Ca2+-permeable AMPA receptors regulate growth of human glioblastoma via Akt activation. J Neurosci 27: 7987-8001, 2007.

32. Lin HI, Lee YJ, Chen BF, Tsai MC, Lu JL, Chou CJ and Jow GM: Involvement of Bcl-2 family, cytochrome $\mathrm{c}$ and caspase 3 in induction of apoptosis by beauvericin in human non-small cell lung cancer cells. Cancer Lett 230: 248-259, 2005.

33. Paulsen M, Ussat S, Jakob M, Scherer G, Lepenies I, Schütze S, Kabelitz D and Adam-Klages S: Interaction with XIAP prevents full caspase-3/-7 activation in proliferating human $\mathrm{T}$ lymphocytes. Eur J Immunol 38: 1979-1987, 2008.

34. Feng J, Zhang S, Wu K, Wang B, Wong JY, Jiang H, Xu R, Ying L, Huang $\mathrm{H}$, Zheng $\mathrm{X}$, et al: Combined effects of suberoylanilide hydroxamic acid and cisplatin on radiation sensitivity and cancer cell invasion in non-small-cell lung cancer. Mol Cancer Ther 15: 842-853, 2016.
35. Rajagopalan P, Alahmari KA, Elbessoumy AA, Balasubramaniam M, Suresh R, Shariff ME and Chandramoorthy HC: Biological evaluation of 2-arylidene-4, 7-dimethyl indan-1-one (FXY-1): A novel Akt inhibitor with potent activity in lung cancer. Cancer Chemother Pharmacol 77: 393-404, 2016.

36. Smardova J, Liskova K, Ravcukova B, Malcikova J, Hausnerova J, Svitakova M, Hrabalkova R, Zlamalikova L, Stano-Kozubik K, Blahakova I, et al: Complex analysis of the p53 tumor suppressor in lung carcinoma. Oncol Rep 35: 1859-1867, 2016.

37. Zhang G, An Y, Lu X, Zhong H, Zhu Y, Wu Y, Ma F, Yang J, Liu Y, Zhou Z, et al: A Novel naphthalimide compound restores p53 function in non-small-cell lung cancer by reorganizing the bak-Bcl-xl complex and triggering transcriptional regulation. J Biol Chem 291: 4211-4225, 2016.

38. Iwamoto FM, Kreisl TN, Kim L, Duic JP, Butman JA, Albert PS and Fine HA: Phase 2 trial of talampanel, a glutamate receptor inhibitor, for adults with recurrent malignant gliomas. Cancer 116: 1776-1782, 2010 